\title{
Survival Strategies and Sustainability of Small and Medium Enterprises in the Oshodi-Isolo Local Government Area of Lagos State
}

\author{
Nkiruka IFEKWEM, ${ }^{1}$ Ogundeinde ADEDAMOLA ${ }^{2}$
}

${ }^{1}$ Department of Business Administration, College of Management Sciences, Bells

University of Technology, Ota, Ogun State, e-mail: nkyifek@yahoo.com

${ }^{2}$ Department of Business Administration, College of Management Sciences, Bells University of Technology, Ota, Ogun State, e-mail: adedamola21@yahoo.com

\begin{abstract}
Small and medium enterprises (SMEs) play an essential role in the sustainable development of countries. They help in employment generation, industrial production increase, and export, social enrichment as well as political stability. This study investigates the survival strategies and sustainability of SMEs using selected small businesses in the OshodiIsolo Local Government Area, Lagos State. It examines the type of growth strategies that SMEs adopt, ascertains what influences their survival strategies as well as the challenges that hinder their growth. Fifty (50) SMEs were randomly sampled. Their owners and managers were interviewed using questionnaires. Data collected were analysed using descriptive statistics and Pearson product-moment correlation coefficient statistics. Our findings reveal that there is a statistically significant relationship between survival strategies and SMEs' sustainability. The major implication of the findings is that maintaining small but committed and motivated employees is critical in guaranteeing the survival of the SMEs in a volatile economy. The study recommends that there be a need for orientation and educational programmes to change the mindset of business owners to enable them to graduate from sole atomistic proprietor devoid of modern scientific business practice and effective succession to corporate status with an apparatus of modern business management practices and corporate vision. Finally, the study further suggests some imperatives for policy makers concerned with promoting small businesses' growth and sustainability in the Oshodi-Isolo Local Government Area of Lagos State.
\end{abstract}

Keywords: economic growth, poverty, government policies, sole ownership JEL Classifications: $\mathrm{O} 1$ 


\section{Introduction}

SMEs have been accepted worldwide as instruments of economic growth and development. Governments, particularly in the developing countries, have made tremendous efforts and established policies towards enhancing the capacity and sustainability of SMEs. However, despite government institutional and policy support, there is a grave concern and scepticism about whether SMEs can bring about economic growth and development, particularly in developing countries. In Nigeria, there have been a series of government interventions to boost the activities of SMEs through the establishment of agencies and programmes to provide consultancy, information, and guidelines to Nigerians who establish and own businesses. Some of these programmes include: Small and Medium Enterprise Equity Investment Scheme (SMEEIS) established in 2001 and the Small and Medium Scale Enterprises Development Agency of Nigeria (SMEDAN) established in 2003. Other agencies include: the National Directorate of Employment (NDE), Skills Acquisition Centre and Industrial Development Centres. SMEs are faced with challenges which affect their ability to function and contribute optimally to the economy. Studies have shown that a significant percentage of SMEs dies before reaching five years of establishment. It is thus imperative that studies be carried out on how these SMEs survive and on the strategies they adopt for their sustainability.

The major objectives of this paper are as follows:

- Ascertain the relationship between growth strategies and the sustainability of SMEs.

- Examine the type of growth strategies adopted.

- Examine the challenges that hinder growth in the selected area.

\section{An Overview of SMEs in Nigeria}

SMEs can be defined in terms of sales volume, number of employees, or investment (Ajide, Hameed, and Oyetade, 2014). A business that is therefore defined as a small- or medium-scale enterprise in a developed country can be regarded as a large-scale enterprise in a developing country. Even in developing countries, this definition changes over time. The European Commission defines SME using three broad parameters: micro-entities, small companies, and medium-sized enterprises. The category of micro-, small- and medium-sized enterprises (SMEs) is made up of enterprises which employ fewer than 250 persons and which have an annual turnover not exceeding 50 million euros and/or an annual balance sheet total not exceeding 43 million euros (European Commission, 2003).

The Central Bank of Nigeria defines SMEs in Nigeria according to asset base and the number of staff employed. These criteria are: asset base between N5 
Million and N500 Million (excluding land and buildings) and a staff strength of between 10 and 300 employees (CBN Guidelines, 2010). The effort to develop a blueprint for SMEs' development in Nigeria continued. This was borne out of the desire of the Federal Government of Nigeria to institute a development paradigm that would ensure Nigeria's position as one of the twenty (20) most industrialized countries of the World.

The objectives and goals to develop SMEs in Nigeria are included in the country's Vision 2020. It is believed that this vision will support SMEs as the main engines of economic growth, a driver of sustainable industrial development, and a globally competitive sector. The objectives as included in Vision 2020:

a. To develop an SME sector that is the driver of the national economic growth and development. This is to be achieved by the following goals:

i. Increasing entrepreneurship and raising employment contribution to $60 \%$ by 2015 and to $80 \%$ by 2020 .

ii. Centralized management, monitoring, coordination, planning, promotion, and development of SMEs.

iii. Contributing $50 \%$ of GDP in 2015 and $75 \%$ by 2020 .

b. To develop a strong, viable, and sustainable SME sector capable of competing globally in terms of quality products and services at competitive prices. This is to be achieved by the following goals:

i. To contribute $50 \%$ of export by 2015 and $80 \%$ by 2020 .

ii. Increase production of capital goods by $40 \%$ annually up to 2020 .

iii. Improve the business environment by raising the country's rating on the "Doing Business" list to at most 80 by 2015 and to at most 50 by 2020 .

c. Develop and improve entrepreneurial skills and competencies of existing and potential entrepreneurs. This is to be achieved by the following goals:

i. Improvement in investment on human capital by $20 \%$ annually up to 2015 and by $15 \%$ in 2020 .

ii. Increase productivity at all micro-, small- and medium-enterprise levels by $20 \%$.

d. Encourage rural transformation and reduce rural-urban migration, achievable by the following goal:

i. Reduce the rural poverty index from $54 \%$ to $30 \%$ in 2015 and to $10 \%$ by 2020.

e. Encourage the use of improved technology in the production of goods and services, achievable by the following goal:

i. To increase the skills and know-how for industrial production and management by $30 \%$ on a yearly basis until 2020 .

f. Increase access to funding and financial services, to be achieved by the following goal: 
i. To increase access to credit by $20 \%$ annually until 2015 and by $10 \%$ yearly up to 2020.

g. Encourage forward and backward linkages with other sectors of the economy, achievable by the following goals:

i. To provide linkage with and be a source of raw materials to large-scale industries.

ii. To effectively utilize locally produced raw materials.

h. The domestic market for SMEs achievable by the following goals:

i. Increase procurement of SME goods and services by $60 \%$ in 2015 and $100 \%$ by 2020 .

ii. Increase government procurement from the SME sector by $50 \%$ annually.

\subsection{Scope and Structure of the Small and Medium Enterprises (SME) Sector}

The SME sector according to Vision 2020 (2009) comprises micro-, small, and medium enterprises, which are distinguished as a group separate from large organizations. The majority of SMEs in Nigeria are family-owned, they have a low capital base, are located in urban and semi-urban areas, and largely reside in the informal sector. The informal sector in Nigeria refers to economic activities in all sectors of the economy that are operated outside the purview of government regulation (Vision 2020, 2009).

As with developed economies, Nigeria, with the introduction of the National Policy on MSMEs, has addressed the issue of definition as to what constitutes micro-, small, and medium enterprises. This classification, also adopted by SMEDAN, defines the size category, number of employees, and asset holdings as shown in Table 1:

Table 1: Structure of the SME subsector

\begin{tabular}{llllc}
\hline S/N & Size category & Employment & $\begin{array}{c}\text { Assets (-N- } \\
\text { Million) } \\
\text { (excl. land and } \\
\text { buildings) }\end{array}$ & $\begin{array}{c}\text { Estimated } \\
\text { Number } \\
\text { (\% of MSMEs) - } \\
2004\end{array}$ \\
\hline 1 & Micro-enterprises & Less than 10 & Less than 5 & 6.7 million (80\%) \\
\hline 2 & Small Enterprises & 10 to 49 & 5 to less than 50 & 1.3 million (15\%) \\
\hline 3 & Medium Enterprises & 50 to 199 & $\begin{array}{l}50 \text { to less than } \\
500\end{array}$ & $420,000(5 \%)$ \\
\hline
\end{tabular}

Source: National Policy on MSMEs. Chemonics International Inc. 2005 as in Report on

Vision 2020 (2009) 
The three categories of enterprises, as defined in the above table, play different roles in the economy and are influenced by the characteristics of operators and the strictness of entry requirements (Vision 2020, 2009).

The following explains the categories of enterprises as described by Vision 2020 (2009):

\subsubsection{Micro-enterprises}

The National Policy on Micro-, Small, and Medium Enterprises in Vision 2020 describes micro-enterprises in Nigeria as those dominated by wholesale and retail trade, manufacturing and vehicle repair/servicing, transport, hotels and restaurants, and building and construction. The majority of the micro-enterprises are informal, family-owned businesses with low output value and low levels of skills and technology.

Micro-enterprises are widespread throughout the nation and numerous due to the simple entry requirements. Targeted interventions in the form of funding, technology upgrade, and training will go a long way in increasing the very low number of micro-enterprises transitioning into SMEs. This will result in the multiplier effects of employment generation and reduction of poverty incidence.

\subsubsection{Small Enterprises}

Most small enterprises are registered businesses and they are usually more organized and efficiently run. Because they have a larger number of well-educated, technically skilled proprietors, they have easier access to bank credits and with targeted assistance and support they offer the highest potential for growth.

\subsubsection{Medium Enterprises}

The formal SMEs sector is dominated by medium enterprises, the majority of which are in the manufacturing, transportation, and ICT sectors. They have better access to credits and are the main recipients of most government initiatives targeted towards SMEs. Government initiatives like SMEDFUND and SMEEIS aimed to cover only enterprises with a maximum asset base of N200 million and those that regularly complied with applicable tax laws. These criteria clearly ruled out most informal businesses providing the majority of employment and constituting about 80 percent of SMEs (Vision 2020, 2009). 


\subsection{Contributions of Small and Medium Enterprises to the Nigerian Economy}

Haruna (2010), Mohammed and Ango (2010), Oyekan (2007), Adima (2003), and many other scholars have identified SMEs as a great importance to the Nigerian economy, considering the following:

- Employment Opportunities: Small-scale enterprises helped to reduce unemployment considering the number of people that are engaged in their operations since most of their operations are labour intensive and they provide employment opportunities at a relatively low capital cost.

- Equitable Distribution of the Nation's Income: Studies have shown that between the rich and the poor the gap is the geographical distribution of income and it is a very large gap. However, small businesses have helped in the redistribution of income by creating a strong middle class.

- Mobilization of Local Resources: There is need to switch emphasis from import-dependent large-scale industries to small enterprises that structure their production processes to depend mostly on local sourcing with locally available resources. This inward-looking process will play a significant role in mobilizing local resources that have been neglected.

- Raw Material Sources: In fact, most automobile-manufacturing plants in Europe and America do not manufacture every bit of the car; rather, they make considerable use of parts most of which are supplied by small-scale industries, e.g. Guinness (Nig.) Plc, Nigeria Breweries Plc, British America Tobacco, Nigeria (BAT) - among others, rely on local farmers for their raw materials.

- Conservation and Generation of Foreign Exchange: A good number of imported consumer goods can be economically produced locally to save and boost foreign exchange, e.g. fruit juice, frozen foods, and beverages are now produced locally in Nigeria and even exported to generate foreign exchange.

- Mitigation of Rural-Urban Migration: Small-scale firms may be a veritable instrument for solving the problem of rural-urban drift. Some small businesses are in rural areas to absorb rural labour. This situation will have a positive impact on agricultural output and a rise in farmers' income, which in turn will encourage rural dwellers to remain in their locality.

- Even Distribution of Industries: The rapid growth in the establishment of small-scale businesses has led to a more even distribution of industries nationwide. 


\subsection{Challenges Confronting Small and Medium Enterprises in the Isolo local government area of Lagos State.}

The following are notable problems facing small-scale owners/entrepreneurs in Isolo:

- Difficulties in Attracting Fund for Expansion: One of the major problems faced by Nigerian entrepreneurs is the issue of financing their operations. The collateral securities and rate of interest required most time by banks go beyond what small-scale businesses can afford, thereby denying their access to bank loans.

- Epileptic Power Supply: Inadequate power supply witnessed in Nigeria has a great deal of adverse effects on the operations of small-scale enterprises. Most small-scale businesses cannot afford to acquire a plant because of its huge financial commitment, and where an enterprise can acquire a plant the cost will reflect on the unit price of their products, thereby leading to higher prices, which may scare the consumers away, especially where products produced by the enterprise have close substitutes.

- Competition/Poor Patronage: Nigerians believe that locally made goods are inferior; so, they prefer patronizing imported goods, thereby hindering the growth and expansion of small-scale industries.

- High Cost of Machinery Maintenance: Nigeria is in need of expatriates whose service fee cannot be compared to that of the local experts, and many enterprises cannot pay for such expatriates' services.

- Inconsistent Government Policies: Inconsistent government policies sometimes create problems for small-scale operations. For instance, if an enterprise imports raw materials and there is a policy banning on such raw materials, the enterprise will find it difficult to survive if there are no available local contents to substitute such materials.

- High Rate of Taxes/Multiple Taxation: Various forms of taxes are imposed on small-scale operations by all tiers of government, which they often find difficult to cope with. These taxes come in the forms of business registration fee, local government fee, value added tax (VAT), excise duties, state tax/state permit, etc. When all these taxes are deducted from the profit made, the remaining amount becomes so little that the enterprise may even find it difficult to pay its workforce.

- Other problems include erratic infrastructural facilities such as poor road network, inadequate pipe-borne water system, frustrating security system, inefficient telecommunication services, etc. 


\section{Overview of Survival Strategies}

The concept of strategies has been used in this research with reference to the future ability of a business to operate ethically and contribute to economic development while improving the quality of life for its workforce, the local and global community as well as future generations (Cralsand and Vereeck, 2004; Yusuf and Dansu, 2013). SMEs are considered sustainable when they can overcome the challenges that stand in their way in the internal and external business environment around. Various researches have brought to the fore of knowledge the existence of strategies considered by SMEs. There exist three basic strategies: Porter's Generic Competitive Strategy (Ansoff's Product), Market Matrix, and Miles and Snow's adaptation strategy.

This study focuses on the Porter's Generic Competitive Strategy for the purpose of analysis of the strategies adopted by the studies on SMEs in Nigeria. The Porter's Generic Competitive Strategy (PGCS) continues to remain a strategy that has been considered and practised intentionally or unintentionally by SMEs. This consideration and practising by SMEs have continued over the years.

Designed by Micheal Porter in 1979, its framework offers three major strategic options to SMEs in the context of competitive advantage and competitive scope. The three options are cost leadership, differentiation, and focus. The theory stresses that for success to be achieved SMEs need to select one of these generic strategies. Otherwise, a phenomenon of "stuck in the middle" may affect them.

Lee, Lim, and Tan (1999), Leitner and Guldenberg (2010), Radford, Addison, and Ahmed (2013), and Tanwar (2013) have all stressed that SMEs are maintaining the generic focus strategy of Porter. Focus strategy has to do with concentrating on the particular market segment(s). This strategy is common among the studied SMEs because of the challenge of resources. These SMEs face a series of difficulties, as mentioned above, that have led them to adopt the focus strategy. The focus generic strategy can be closely related to Selten's (1978) work. Selten's work, which has been taken further by literature on various small business ventures (Kao, 1981; Weinstein, 1994; Kotler, 1996; Leithner and Guldenberg, 2010), stresses on the niching strategy: filling market gaps by offering products differentiated from (but a substitute to) that of the "bigger" rivals. Various SMEs taken into consideration practised this type of strategy as it increases their income/profit.

However, a considerable amount of the SMEs studied had a mix of the three survival strategies proposed by Porter. These strategies included cost leadership and differentiation. Cost leadership has to do with having lowest per unit cost in the industry (field study, 2015). The SMEs studied were said to have reduced the costs of their "big rivals" (field study, 2015). These SMEs may be said to have a price war with the larger firms in the LGA (field study, 2015). The drive for these SMEs is that in the long run they might have higher profits than their rivals. 
However, SMEs which have tried this strategy were often too small to follow up (Ebben (2005), Johnson (2005), and Leitner and Guldenberg (2009)). Despite this challenge, they still made use of it.

Another strategy observed was the differentiation generic competitive strategy. Here, SMEs created something that is perceived industry-wide as being unique.

\section{Methodology}

This study investigated the survival strategies and sustainability of SMEs using selected small businesses in the Oshodi-Isolo Local Government, Lagos State. Using the selected owners of small businesses in Oshodi-Isolo, Lagos State, as the population of interest, a survey research design was adopted in this study. 50 SMEs were randomly sampled and their owners and managers interviewed using a questionnaire.

The data collected were analysed using descriptive statistic and Pearson's product-moment correlation coefficient statistics was used to test the hypotheses with the aid of the Statistical Package for Social Science (SPSS) Version 21.0.

\section{Analysis and Findings}

Table 6 shows a summary of the demographic profiles of respondents, where $100 \%$ of the respondents had trading named as their nature of business: $16 \%$ have been in existence for 20 years, $28 \%$ for a period between 11 and 20 years, and $56 \%$ for ten years or less. $32 \%$ of them had an educational qualification of primary 6 and below, $52 \%$ had a senior school certificate, and $16 \%$ had a higher education diploma. $90 \%$ of them were first-generation, while $10 \%$ of them second-generation businesspersons. As for their ages: $24 \%$ of them were below 30 years, $54 \%$ of them were between 30 and 45 years, and $22 \%$ of them were above 45 years. $24 \%$ of these respondents were single and $76 \%$ of them were married. 
Table 2. Summary of the demographic profiles of respondents

\begin{tabular}{llcc}
\hline Variables & Level & $\begin{array}{c}\text { No of } \\
\text { respondents \% }\end{array}$ & \% Total \\
\hline Nature of Business & Trading & $50(100 \%)$ & $100 \%$ \\
\hline Year of Existence & 10 years and below & $28(56.0)$ & \\
& 11-20 years & $14(28.0)$ & \\
& Above 20 years & $8(16.0)$ & $50(100.0)$ \\
\hline & & & \\
\hline Educational qualification & Primary 6 and below & $16(32.0)$ & \\
of the owner & Senior school certificate & $26(52.0)$ & \\
& Higher education & $8(16.0)$ & \\
\hline & & & $50(100.0)$ \\
\hline Generation of business & $1^{\text {st }}$ & $45(90.0)$ & \\
& $2^{\text {nd }}$ & $5(10.0)$ & \\
& $3^{\text {rd }}$ & & \\
\hline & & $12(24.0)$ & \\
\hline Age of respondent & Below 30 & $27(54.0)$ & \\
& 30-45 & $11(22.0)$ & \\
\hline & Above 45 & $12(24.0)$ & \\
\hline Marital status of & Single & $38(76.0)$ & \\
respondent & Married & & $50(100.0)$ \\
\hline
\end{tabular}

Regarding survival strategy in terms of SMEs in Oshodi-Isolo LGA, 62\% of the respondents agreed that the entrepreneur takes formal responsibility for the business' strategic management, 20\% strongly agreed, 10\% disagreed, $6 \%$ strongly disagreed, and $2 \%$ were indifferent. $60 \%$ of the respondents agreed that survival strategies are top priority activities performed on a regular basis, $22 \%$ strongly agreed, $8 \%$ disagreed, $6 \%$ were indifferent, and $4 \%$ strongly disagreed. $62 \%$ agreed that the business follows a defined set of procedures in their survival strategy process, $13 \%$ strongly disagreed, $8 \%$ disagreed, $2 \%$ strongly disagreed, and none were indifferent. $64 \%$ of the respondents strongly agreed that business provides resources earmarked specifically for the sustenance of business, $24 \%$ agreed, $8 \%$ disagreed, $4 \%$ strongly disagreed, and none of them were indifferent.

With respect to questions concerning the growth strategy adopted, $44 \%$ of the respondents disagreed that small businesses adopted integrative strategy as one of the growth strategies in recent times, $24 \%$ agreed, $14 \%$ strongly agreed, $10 \%$ strongly disagreed, and $8 \%$ were indifferent. $58 \%$ of the respondents agreed that small businesses adopt diversification strategy as one of the growth strategies in recent times, $24 \%$ strongly agreed, $10 \%$ were indifferent, $6 \%$ disagreed, and $2 \%$ 
strongly disagreed. 66\% agreed that small businesses pursued and implemented a corporate strategy which had resulted their sustainability, $20 \%$ strongly agreed, $6 \%$ strongly disagreed, $6 \%$ disagreed, and $2 \%$ were indifferent. $64 \%$ of the respondents agreed that small businesses pursued and implemented a generic competitive strategy which had resulted their sustainability, $26 \%$ strongly agreed, $6 \%$ disagreed, $4 \%$ strongly disagreed, while none of them were indifferent. $67 \%$ of the respondents agreed that small businesses pursued and implemented differentiation strategy which had resulted their sustainability, $16 \%$ strongly agreed, $6 \%$ disagreed, $2 \%$ strongly disagreed, and none were indifferent.

On questions regarding what can influence survival strategy, $56 \%$ strongly agreed that there had been a strategic consistency of actions of small business owners in sustaining their businesses, $26 \%$ agreed, $10 \%$ disagreed, $4 \%$ strongly disagreed, and $4 \%$ were indifferent. $62 \%$ strongly agreed that the implemented survival strategies have challenged and motivated key personnel to lend their support, $10 \%$ agreed, $8 \%$ disagreed, $6 \%$ strongly disagreed, and $4 \%$ were indifferent. 58\% agreed that their businesses had recorded increase in employee performance in recent times due to the survival strategies adopted, $24 \%$ strongly disagreed, $10 \%$ were indifferent, $6 \%$ strongly disagreed, and $2 \%$ disagreed. $42 \%$ agreed that the survival strategies formulated and implemented were consistent with goals and policies, $26 \%$ disagreed, $14 \%$ strongly disagreed, $12 \%$ disagreed, and $3 \%$ were indifferent.

On questions regarding the relationship between survival strategies of SMEs and their sustainability, $60 \%$ agreed that survival strategies adopted by SMEs gave them a competitive advantage over others, $32 \%$ strongly agreed, $4 \%$ strongly disagreed, $4 \%$ disagreed, and none were indifferent. $44 \%$ of the respondents agreed that there had been an effective implementation of survival strategies by small business owners, 36\% strongly agreed, $12 \%$ strongly disagreed, $4 \%$ disagreed, and $4 \%$ were indifferent. $48 \%$ of the respondents agreed that there was a significant link between survival strategy and profitability, 36\% strongly agreed, $8 \%$ disagreed, $4 \%$ strongly disagreed, and $4 \%$ were indifferent.

Table 3. Analysis of responses from respondents

\begin{tabular}{|c|c|c|c|c|c|}
\hline $\begin{array}{l}\text { How survival strategies have been carried } \\
\text { out in SMEs in Oshodi-Isolo LGA }\end{array}$ & SD & D & IND & $\bar{A}$ & SA \\
\hline $\begin{array}{l}\text { The entrepreneur takes for } \\
\text { for the business' strategic } n\end{array}$ & $\begin{array}{c}3 \\
(6 \%) \\
\end{array}$ & $(10 \%)$ & $\begin{array}{c}1 \\
(2 \%) \\
\end{array}$ & $\begin{array}{c}32 \\
(62 \%) \\
\end{array}$ & $\begin{array}{c}10 \\
(20 \%)\end{array}$ \\
\hline & $\begin{array}{c}2 \\
(4 \%) \\
\end{array}$ & $\begin{array}{c}4 \\
(8 \%) \\
\end{array}$ & $\begin{array}{c}3 \\
(6 \%) \\
\end{array}$ & $\begin{array}{c}30 \\
(60 \%) \\
\end{array}$ & $\begin{array}{c}11 \\
(22 \%) \\
\end{array}$ \\
\hline $\begin{array}{l}\text { Businesses follow a defined set of procedur } \\
\text { in their survival strategy process. }\end{array}$ & $\begin{array}{c}2 \\
(4 \%)\end{array}$ & $\begin{array}{c}4 \\
(8 \%)\end{array}$ & $\begin{array}{ll}- \\
-\end{array}$ & $\begin{array}{c}31 \\
(62 \%)\end{array}$ & $\begin{array}{c}13 \\
(26 \%)\end{array}$ \\
\hline $\begin{array}{l}\text { Businesses provide resources earmarked } \\
\text { specifically for sustenance of business. }\end{array}$ & $\begin{array}{c}2 \\
(4 \%) \\
\end{array}$ & $\begin{array}{c}4 \\
(8 \%) \\
\end{array}$ & $\begin{array}{ll}- \\
-\end{array}$ & $\begin{array}{c}12 \\
(24 \%) \\
\end{array}$ & $\begin{array}{c}32 \\
(64 \%) \\
\end{array}$ \\
\hline
\end{tabular}




\begin{tabular}{|c|c|c|c|c|c|}
\hline $\begin{array}{l}\text { How survival strategies have been carried } \\
\text { out in SMEs in Oshodi-Isolo LGA }\end{array}$ & SD & $\mathbf{D}$ & IND & $\mathbf{A}$ & SA \\
\hline \multicolumn{6}{|l|}{ Type of the growth strategy adopted } \\
\hline $\begin{array}{l}\text { Small businesses adopt integrative strategy as } \\
\text { one of the growth strategies in recent times. }\end{array}$ & $\begin{array}{c}5 \\
(10 \%) \\
\end{array}$ & $\begin{array}{c}22 \\
(44 \%) \\
\end{array}$ & $\begin{array}{c}4 \\
(8 \%) \\
\end{array}$ & $\begin{array}{c}12 \\
(24 \%) \\
\end{array}$ & $\begin{array}{c}7 \\
(14 \%) \\
\end{array}$ \\
\hline $\begin{array}{l}\text { Small businesses adopt diversification } \\
\text { strategy as one of the growth strategies in } \\
\text { recent times. }\end{array}$ & $\begin{array}{c}1 \\
(2 \%)\end{array}$ & $\begin{array}{c}3 \\
(6 \%)\end{array}$ & $\begin{array}{c}5 \\
(10 \%)\end{array}$ & $\begin{array}{c}29 \\
(58 \%)\end{array}$ & $\begin{array}{c}12 \\
(24 \%)\end{array}$ \\
\hline $\begin{array}{l}\text { Small businesses pursue and implement } \\
\text { a corporate strategy which results in their } \\
\text { sustainability. }\end{array}$ & $\begin{array}{c}3 \\
(6 \%)\end{array}$ & $\begin{array}{c}3 \\
(6 \%)\end{array}$ & $\begin{array}{c}1 \\
(2 \%)\end{array}$ & $\begin{array}{c}33 \\
(66 \%)\end{array}$ & $\begin{array}{c}10 \\
(20 \%)\end{array}$ \\
\hline $\begin{array}{l}\text { Small businesses pursue and implement a } \\
\text { generic competitive strategy which results in } \\
\text { their sustainability. }\end{array}$ & $\begin{array}{c}2 \\
(4 \%)\end{array}$ & $\begin{array}{c}3 \\
(6 \%)\end{array}$ & - & $\begin{array}{c}32 \\
(64 \%)\end{array}$ & $\begin{array}{c}13 \\
(26 \%)\end{array}$ \\
\hline $\begin{array}{l}\text { Small businesses pursue and implement } \\
\text { differentiation strategy which results in their }\end{array}$ & $\begin{array}{c}1 \\
(2 \%)\end{array}$ & $\begin{array}{c}3 \\
(6 \%)\end{array}$ & - & $\begin{array}{c}38 \\
(76 \%)\end{array}$ & $\begin{array}{c}8 \\
(16 \%)\end{array}$ \\
\hline
\end{tabular}

\section{What can influence survival strategy}

\begin{tabular}{|c|c|c|c|c|c|}
\hline $\begin{array}{l}\text { There has been a strategic consistency of } \\
\text { actions of small business owners in sustaining } \\
\text { their businesses. }\end{array}$ & $\begin{array}{c}2 \\
(4 \%)\end{array}$ & $\begin{array}{c}5 \\
(10 \%)\end{array}$ & $\begin{array}{c}2 \\
(4 \%)\end{array}$ & $\begin{array}{c}13 \\
(26 \%)\end{array}$ & $\begin{array}{c}28 \\
(56 \%)\end{array}$ \\
\hline $\begin{array}{l}\text { The survival strategies implemented have } \\
\text { challenged and motivated key personnel to } \\
\text { lend their support. }\end{array}$ & $\begin{array}{c}3 \\
(6 \%)\end{array}$ & $\begin{array}{c}4 \\
(8 \%)\end{array}$ & $\begin{array}{c}2 \\
(4 \%)\end{array}$ & $\begin{array}{c}10 \\
(20 \%)\end{array}$ & $\begin{array}{c}31 \\
(62 \%)\end{array}$ \\
\hline $\begin{array}{l}\text { This business has recorded increase in } \\
\text { employee performance in recent times due to } \\
\text { the survival strategies adopted. }\end{array}$ & $\begin{array}{c}3 \\
(6 \%)\end{array}$ & $\begin{array}{c}1 \\
(2 \%)\end{array}$ & $\begin{array}{c}5 \\
(10 \%)\end{array}$ & $\begin{array}{c}29 \\
(58 \%)\end{array}$ & $\begin{array}{c}12 \\
(24 \%)\end{array}$ \\
\hline $\begin{array}{l}\text { The survival strategies formulated and } \\
\text { implemented are consistent with the goals }\end{array}$ & $\begin{array}{c}7 \\
(14 \%)\end{array}$ & $\begin{array}{c}6 \\
(12 \%)\end{array}$ & $\begin{array}{c}3 \\
(6 \%)\end{array}$ & $\begin{array}{c}21 \\
(42 \%)\end{array}$ & $\begin{array}{c}13 \\
(26 \%)\end{array}$ \\
\hline
\end{tabular}

\begin{tabular}{|c|c|c|c|c|c|}
\hline \multicolumn{6}{|l|}{$\begin{array}{l}\text { Relationship between the survival strategies } \\
\text { of SMEs and their sustainability }\end{array}$} \\
\hline $\begin{array}{l}\text { Survival strategies adopted by SMEs give } \\
\text { them competitive advantage over others. }\end{array}$ & $\begin{array}{c}2 \\
(4 \%) \\
\end{array}$ & $\begin{array}{c}2 \\
(4 \%) \\
\end{array}$ & - & $\begin{array}{c}30 \\
(60 \%)\end{array}$ & $\begin{array}{c}16 \\
(32 \%)\end{array}$ \\
\hline $\begin{array}{l}\text { There has been an effective implementation of } \\
\text { survival strategies by small business owners. }\end{array}$ & $\begin{array}{c}6 \\
(12 \%) \\
\end{array}$ & $\begin{array}{c}2 \\
(4 \%) \\
\end{array}$ & $\begin{array}{c}2 \\
(4 \%) \\
\end{array}$ & $\begin{array}{c}22 \\
(44 \%) \\
\end{array}$ & $\begin{array}{c}18 \\
(36 \%) \\
\end{array}$ \\
\hline $\begin{array}{l}\text { There is a significant link between survival } \\
\text { strategy and profitability. }\end{array}$ & $\begin{array}{c}2 \\
(4 \%)\end{array}$ & $\begin{array}{c}4 \\
(8 \%)\end{array}$ & $\begin{array}{c}2 \\
(4 \%)\end{array}$ & $\begin{array}{c}24 \\
(48 \%)\end{array}$ & $\begin{array}{c}18 \\
(36 \%)\end{array}$ \\
\hline \multicolumn{6}{|l|}{$\begin{array}{l}\text { Other challenges that affect the survival of } \\
\text { SMEs in Oshodi-Isolo LGA }\end{array}$} \\
\hline $\begin{array}{l}\text { The wrong line of business could be a } \\
\text { challenge slowing down the growth of SMEs. }\end{array}$ & $\begin{array}{c}1 \\
(2 \%) \\
\end{array}$ & $\begin{array}{c}4 \\
(8 \%) \\
\end{array}$ & - & $\begin{array}{c}33 \\
(66 \%) \\
\end{array}$ & $\begin{array}{c}12 \\
(24 \%) \\
\end{array}$ \\
\hline Lack of succession planning. & $\begin{array}{c}1 \\
(2 \%) \\
\end{array}$ & $\begin{array}{c}4 \\
(8 \%) \\
\end{array}$ & - & $\begin{array}{c}32 \\
(64 \%) \\
\end{array}$ & $\begin{array}{c}13 \\
(26 \%) \\
\end{array}$ \\
\hline Inadequate setup capital. & - & $\begin{array}{c}2 \\
(4 \%) \\
\end{array}$ & $\begin{array}{c}1 \\
(2 \%) \\
\end{array}$ & $\begin{array}{c}15 \\
(30 \%) \\
\end{array}$ & $\begin{array}{c}32 \\
(64 \%) \\
\end{array}$ \\
\hline Improper keeping of the book of accounts. & $\begin{array}{c}2 \\
(4 \%) \\
\end{array}$ & $\begin{array}{c}3 \\
(6 \%) \\
\end{array}$ & $\begin{array}{c}2 \\
(4 \%) \\
\end{array}$ & $\begin{array}{c}30 \\
(60 \%) \\
\end{array}$ & $\begin{array}{c}13 \\
(26 \%) \\
\end{array}$ \\
\hline
\end{tabular}


The test of hypothesis indicated that there is a significant relationship between survival strategies and the small- and medium-scale firms' sustainability. The findings revealed that there is a statistically significant relationship between survival strategies and SMEs' sustainability.

According to the findings, this is as a result of survival strategies adopted by small firms which give them a competitive advantage over others, effective implementation of survival strategies by the small business owners, and the link between survival strategies and profitability.

Another finding of the study identifies the survival strategies that sustain small and medium enterprises in the Oshodi-Isolo Local Government as the entrepreneur's formal responsibility for the organization's strategic business management. Survival strategies are top priority activity, performed on a regular basis by small businesses. Small businesses provide resources (managers' time, money, staff support, among others) earmarked specifically to sustain their businesses. They also follow a defined set of procedures in their strategic survival process.

The finding also indicated the type of survival growth strategies adopted by small and medium enterprises' management. Among them, there are: integrative strategy, diversification strategy, differentiation strategy, generic competitive strategy, and corporate strategy, which resulted their sustainability within a particular period.

Those factors were also found effective that can influence survival strategies in small and medium enterprises in the Oshodi-Isolo Local Government. Among these are the strategic consistency of small business owners in sustaining their businesses, the survival strategies implemented, identification of purposes, plans, and actions to achieve the objective, and coherence of the survival strategies formulated and applied in accordance with the goals and policies.

However, the study found that there are challenges that slow down the growth of SMEs in the Oshodi-Isolo Local Government, which are: the wrong line of business, lack of a succession plan, small setup capital, and improper keeping of the book of accounts. This is in agreement with the work of Ifekwem, Oghojafor, and Kuye (2011), who examined the growth, sustainability, and inhibiting factors of the family-owned businesses in the south-east of Nigeria. The researchers found that businesses suffered many management and attitudinal problems ranging from lack of succession plan, small setup capital, wrong line of business, poor bookkeeping, individualistic spirit, lack of planning and basic information, and lack of political awareness among others. The conclusion is that businesses start and fail, with the owners rarely succeeding. 
Table 4. Descriptive statistics

\begin{tabular}{lccc}
\hline & Mean & $\begin{array}{c}\text { Std. } \\
\text { Deviation }\end{array}$ & $\mathrm{N}$ \\
\hline $\begin{array}{l}\text { Survival strategies adopted by SMEs give them } \\
\text { competitive advantage over others. }\end{array}$ & 4.120 & .9179 & 50 \\
\hline $\begin{array}{l}\text { An effective implementation of survival strategies } \\
\text { by small business owners }\end{array}$ & 3.880 & 1.2879 & 50 \\
\hline $\begin{array}{l}\text { Significant link between survival strategy and } \\
\text { profitability }\end{array}$ & 4.040 & 1.0490 & 50 \\
\hline
\end{tabular}

Table 5. Correlations

\begin{tabular}{|c|c|c|c|c|}
\hline & & $\begin{array}{c}\text { Survival } \\
\text { strategies adopted } \\
\text { by SMEs give } \\
\text { them competitive } \\
\text { advantage over } \\
\text { others. }\end{array}$ & $\begin{array}{c}\text { An effective } \\
\text { implementation } \\
\text { of survival } \\
\text { strategies by } \\
\text { small business } \\
\text { owners }\end{array}$ & $\begin{array}{c}\text { Significant } \\
\text { link between } \\
\text { survival } \\
\text { strategy and } \\
\text { profitability }\end{array}$ \\
\hline \multirow{3}{*}{$\begin{array}{l}\text { Survival strategies } \\
\text { adopted by } \\
\text { SMEs give them } \\
\text { competitive } \\
\text { advantage over } \\
\text { others. }\end{array}$} & $\begin{array}{l}\text { Pearson's } \\
\text { correlation }\end{array}$ & 1 & $.807^{* *}$ & $.885^{* *}$ \\
\hline & Sig. (2-tailed) & & .000 & .000 \\
\hline & $\mathrm{N}$ & 50 & 50 & 50 \\
\hline \multirow{3}{*}{$\begin{array}{l}\text { An effective } \\
\text { implementation of } \\
\text { survival strategies } \\
\text { by small business } \\
\text { owners }\end{array}$} & $\begin{array}{l}\text { Pearson's } \\
\text { correlation }\end{array}$ & $.807^{* *}$ & 1 & $.970^{* *}$ \\
\hline & Sig. (2-tailed) & .000 & & .000 \\
\hline & $\mathrm{N}$ & 50 & 50 & 50 \\
\hline \multirow{3}{*}{$\begin{array}{l}\text { Significant sink } \\
\text { between survival } \\
\text { strategy and } \\
\text { profitability }\end{array}$} & $\begin{array}{l}\text { Pearson's } \\
\text { correlation }\end{array}$ & $.885^{* *}$ & $.970^{* *}$ & 1 \\
\hline & Sig. (2-tailed) & .000 & .000 & \\
\hline & $\mathrm{N}$ & 50 & 50 & 50 \\
\hline
\end{tabular}

\section{Recommendations}

The study, therefore, recommends that there be a need for orientation and educational programmes to change the mindset of business owners to enable them to graduate from sole atomistic proprietors devoid of modern scientific business practice and an effective succession to corporate status with an apparatus of modern business management practices and corporate vision.

It is strongly recommended that business owners should invest heavily in training and courses locally and abroad to sensitize, orientate, and change their 
mindset as well as adequately develop their management skills and abilities. It is also imperative for business owners to properly scan the Nigerian business environment so as to identify the opportunities and threats therein, and develop the various techniques that will help them to adapt to the changing environments as they emerge.

The government should get more involved in the growth, development, and sustainability of SMEs within the country.

The government will need to institute the right kind of programmes and policies that aim at driving a respectable percentage of the large number of informal micro-enterprises into the formal sector and facilitate the transition of small and medium enterprises to medium- and large-scale enterprises respectively.

Finally, the study further suggests some imperatives for policy makers concerned with promoting small businesses' growth and sustainability in the Isolo Local Government Area of Lagos State.

\section{Conclusions}

From the ongoing discussion wherein there is a broad availability of literature on challenges SMEs are facing in the business environment within the dynamic nature of the Nigerian economy, SMEs still constitute a vital importance to economy. Confronted with a stream of numerous challenges, they still strategize on various methods of survival that eventually sustain them.

Survival strategies have been developed, which this research has synchronized with Porter's Generic Strategies (1980). Theses generic strategies have immensely contributed to the growth and sustainability of the studied SMEs.

They serve as the running engine through which the economy survives. They contribute immensely to the development of entrepreneurial growth as these SMEs try to overcome the overworked challenges.

Suggestion for further studies:

Although this study sought to synchronize Porter's Generic Competitive Strategy with the survival strategies adopted by the studied SMEs, it failed to analyse other survival strategy frameworks developed by other scholars.

The study's focus is only on the Oshodi-Isolo Local Government Area. There are also other LGAs within the State which the results from this study can be applied to. Finally, can the study of the survival strategy employed by SMEs in the Oshodi-Isolo L.G.A. be applied to other LGAs in Lagos? 


\section{References}

Adebisi, Sunday A.; Gloria C. Alaneme; Aiwanehi B. Ofuani. (2015). Challenges of finance and the performance of small and medium enterprises (SMEs) in Lagos State. Developing Country Studies 5(8): 46-57.

Adegbite, Oyeyemi. (2001). Business incubators and small enterprise development: the Nigerian experience. Small Business Economics 17(3): 157-166.

Ajide, Folorunsho M.; Raimi A. Hameed; John A. Oyetade (2014). Environmental sustainability and financial performance of small and medium Enterprises (SMEs) in Nigeria: A study of selected firms in Lagos State. International Journal of Management Sciences and Humanities 2(2): 39-55.

Ayopo, Babajide A. (2011). Effects of microfinance on micro and small enterprises (MSEs) in Southwest Nigeria. Ota: Covenant University.

Bamidele, Rasak. (2012). Small and medium scale enterprises (smes): a panacea for economic growth in Nigeria. Journal of Management and Corporate Governance 4: 83-98.

Basil, Anthony N. (2005). Small and medium enterprises (SMEs) in Nigeria: problems and prospoects. St Clements University.

Esuh, Ossai-Igwe L.; Isaiah O. Adebayo. (2012). Is small and medium enterprises (SMEs) an entrepreneurship? International Journal of Academic Research in Business and Social Sciences 2(1): 487-496.

European Commission. (2003). Commission. Official Journal of the European Union. 36-41.

Ojo, Olu. (2009). Impact of microfinance on entrepreneurial development: The case of Nigeria. The International Conference on Administration and Business. Romania: ResearchGate. 536-545.

Omah, Ishmael; Stella T. Durowoju; Abayomi O. Adeoye; Ayobami F. Elegunde. (2012). Post-bank consolidation: A debacle in the survival of SMEs in Nigeria An empirical study. Australian Journal of Business and Management Research 2(8): 1-6.

Osotimehin, K. O.; Charles A. Jegede; Babatunde H. Akinlabi; O. T. Olajide. (2012). An evaluation of the challenges and prospects of micro and small scale enterprises development in Nigeria. American International Journal of Contemporary Research. 174-185.

Yusuf, Tajudeen O.; Francis S. Dansu. (2013). SMEs, business risks and sustainability in Nigeria. European Journal of Business and Social Sciences 2(9): 76-94. 